\title{
Two new species in a new genus and a critical revision of Brachybasidiaceae (Exobasidiales, Basidiomycota) in honor of Franz Oberwinkler
}

\author{
M. Piepenbring ${ }^{1}$ (D) M. Hartmann ${ }^{1} \cdot$ T. A. Hofmann ${ }^{2} \cdot$ M. Lutz $^{3}$ \\ Received: 2 September 2019 / Revised: 21 January 2020 / Accepted: 23 January 2020 \\ (C) The Author(s) 2020
}

\begin{abstract}
The Brachybasidiaceae are a family of 22 known species of plant-parasitic microfungi belonging to Exobasidiales, Basidiomycota. Within this family, species of the largest genus Kordyana develop balls of basidia on top of stomatal openings. Basidial cells originate from fungal stroma filling substomatal chambers. Species of Kordyana typically infect species of Commelinaceae. During fieldwork in the neotropics, fungi morphologically similar to Kordyana spp. were found on Goeppertia spp. (syn. Calathea spp., Marantaceae), namely on G. panamensis in Panama and on G. propinqua in Bolivia. These specimens are proposed as representatives of a genus new to science, Marantokordyana, based on the distinct host family and molecular sequence data of ITS and LSU rDNA regions. The specimens on the two host species represent two species new to science, M. oberwinkleriana on G. panamensis and M. boliviana on G. propinqua. They differ by the size and shape of their basidia, molecular sequence data of ITS and LSU rDNA regions, and host plant species. In the past, the understanding of Brachybasidiaceae at order and family level was significantly improved by investigation realized by Franz Oberwinkler and his collaborators at the University of Tübingen, Germany. On species level, however, our knowledge is still very poor due to incomplete species descriptions of several existing names in literature, scarceness of specimens, as well as sequence data lacking for many taxa and for further barcode regions. Especially species of Kordyana and species of Dicellomyces are in need of revision.
\end{abstract}

Keywords Bolivia $\cdot$ Calathea $\cdot$ Dicellomyces $\cdot$ Kordyana $\cdot$ Marantaceae $\cdot$ Panama

This article is part of the "Topic collection on Basidiomycote Mycology in honor of Franz Oberwinkler who passed away in March 2018"

Section Editor: Dominic Begerow

Electronic supplementary material The online version of this article (https://doi.org/10.1007/s11557-020-01564-w) contains supplementary material, which is available to authorized users.

M. Piepenbring

piepenbring@bio.uni-frankfurt.de

1 Department of Mycology, Goethe University Frankfurt am Main, Biologicum, Max-von-Laue-Str. 13, 60438 Frankfurt am Main, Germany

2 Mycological Research Center (CIMi), Herbarium UCH, Autonomous University of Chiriquí (UNACHI), 0427 David, Chiriquí Province, Panama

3 Plant Evolutionary Ecology, Institute of Evolution and Ecology, University of Tübingen, Auf der Morgenstelle 5, 72076 Tübingen, Germany

\section{Introduction}

The Exobasidiomycetes (Ustilaginomycotina, Basidiomycota) include orders traditionally considered smut fungi because of the presence of thick-walled probasidia (teliospores), like in Doassansiales, Entylomatales, Georgefischeriales, and Tilletiales. This class also includes fungi without teliospores mainly in Ceraceosorales, Exobasidiales, and Microstromatales (Begerow et al. 2002, 2018). On the basis of different types of soral structures, basidia, and ultrastructural characteristics, Bauer et al. $(1998,2001)$ distinguished four families within the Exobasidiales, namely Brachybasidiaceae, Cryptobasidiaceae, Exobasidiaceae, and Graphiolaceae. These groups have also been treated as orders in the past as well as recently by Oberwinkler (2012a, b). Distinctive characteristics relevant for the concept of Exobasidiales and morphologically closely related 
Table 1 Synopsis of distinctive characteristics of Exobasidiomycetes, Exobasidiales and morphologically close orders, families of Exobasidiales, and genera of Brachybasidiaceae. Systematic groups that are not in the focus of the present publication are separated from Brachybasidiaceae and Exobasidiales by bold lines. The genus proposed as new in the present publication is presented on a gray background. For "Dicellomyces" scirpi, see discussion. In addition to literature cited in the text, information published by Cunningham et al. (1976) and Begerow et al. $(2006,2014)$ was used for Ceraceosorales as well as by Oberwinkler et al. (1982) and Piepenbring et al. (2012a) for Graphiolaceae

\begin{tabular}{|c|c|c|c|c|c|}
\hline \multicolumn{6}{|c|}{$\begin{array}{c}\text { Exobasidiomycetes } \\
\text { - parasitic on plants, mostly on leaves } \\
\text { - mostly with holobasidia, often growing out of thick-walled probasidia (teliospores) } \\
\text { - asexual growth as yeasts or with hyphae and yeast-like conidia } \\
\text { - host-parasite interaction with complex interaction apparatus }\end{array}$} \\
\hline \multicolumn{2}{|l|}{ Exobasidiales } & $\begin{array}{l}\text { Ceraceos } \\
\text { basidia } \\
\text { - without teliospores } \\
\text { - protruding through epide } \\
\text { - forming sorus-like hymer } \\
\text { - carrying } 2 \text { basidiospores } \\
\text { - sometimes with probasid } \\
\text { basidiospores } \\
\text { - septate upon germinatior } \\
\text { - germinate with hyphae a }\end{array}$ & $\begin{array}{l}\text { orales } \\
\text { mis or stomata } \\
\text { a } \\
\text { on sterigmata } \\
\text { al sacs } \\
\text { d conidia }\end{array}$ & $\begin{array}{l}\text { basidia } \\
\text { - without telio } \\
\text { - protruding th } \\
\text { - carrying mor } \\
\text { directly on the } \\
\text { - sometimes } \\
\\
\text { basidiospore } \\
\text { - germinate fo }\end{array}$ & $\begin{array}{l}\text { icrostromatales } \\
\text { pores } \\
\text { ough stomata } \\
\text { than } 2 \text {, mostly } 6 \text { basidiospores } \\
\text { basidial cell (gastroid) } \\
\text { ith probasidial sacs } \\
\text { ming globose yeast cells }\end{array}$ \\
\hline $\begin{array}{l}\quad \text { Brachybasidiaceae } \\
\text { hosts } \\
\text { - mostly monocots } \\
\text { - without galls } \\
\text { basidia } \\
\text { - break through host tissue or } \\
\text { develop through stomatal openings } \\
\text { - carrying } 2 \text { basidiospores on } \\
\text { sterigmata } \\
\text { - sometimes with probasidial sacs } \\
\text { basidiospores } \\
\text { - blastosporic } \\
\text { - often in pairs } \\
\text { - thin-walled } \\
\text { - smooth } \\
\text { - hyaline }\end{array}$ & $\begin{array}{l}\text { host } \\
\text { - dicc } \\
\text { - with } \\
\text { basic } \\
\text { - dev } \\
\text { - carr } \\
\text { most } \\
\text { (gast } \\
\text { - no } \\
\text { basic } \\
\text { - blas } \\
\text { - thic } \\
\text { - orn } \\
\text { - slig }\end{array}$ & $\begin{array}{l}\text { yptobasidiaceae } \\
\text { mostly Lauraceae } \\
\text { Ils of various host organs } \\
\text { inside host tissue } \\
4 \text { or more basidiospores } \\
\text { irectly on the basidial cell } \\
\text { asidial sacs } \\
\text { poric } \\
\text { alled } \\
\text { anted } \\
\text { pigmented }\end{array}$ & $\begin{array}{l}\quad \text { Exob } \\
\text { hosts } \\
\text { - dicots, mostly } \\
\text { - often with gal } \\
\text { host organs } \\
\text { basidia } \\
\text { - break througl } \\
\text { develop throug } \\
\text { - carrying 2-4- } \\
\text { sterigmata orie } \\
\text { - rarely probas } \\
\text { basidiospore } \\
\text { - ballistosporic } \\
\text { - thin-walled } \\
\text { - smooth } \\
\text { - hyaline }\end{array}$ & $\begin{array}{l}\text { lceae } \\
\text { ceae } \\
\text { led by various } \\
\text { issue or } \\
\text { tatal openings } \\
\text { iospores on } \\
\text { baxially } \\
\text { ickenings }\end{array}$ & $\begin{array}{l}\quad \text { Graphiolaceae } \\
\text { hosts } \\
\text { - Arecaceae } \\
\text { - without galls } \\
\text { basidia } \\
\text { - in black, cup-shaped peridia } \\
\text { - in chains mixed with elaters } \\
\text { - carrying 2-8 basidiospores } \\
\text { laterally, directly on the basidial cell } \\
\text { (gastroid) } \\
\text { basidiospores } \\
\text { - blastosporic } \\
\text { - thick-walled } \\
\text { - ornamented } \\
\text { - slightly pigmented } \\
\text { - break into two part spores }\end{array}$ \\
\hline $\begin{array}{l}\text { Brachybasidium (1 species) } \\
\text { hosts } \\
\text { - Arecaceae } \\
\text { basidia } \\
\text { - in suprastomatal balls } \\
\text { - develop from suprastomatal } \\
\text { probasidia } \\
\text { - without paraphyses } \\
\text { conidia - unknown }\end{array}$ & $\begin{array}{l}\text { Dice } \\
\text { host } \\
\text { - Poa } \\
\text { basi } \\
\text { - in d } \\
\text { breal } \\
\text { - thir } \\
\text { - with } \\
\text { coni }\end{array}$ & $\begin{array}{l}\text { myces (1+1 doubtful sp.) } \\
\text { e (Arecaceae) } \\
\text { id, gelatinous basidiocarps } \\
\text { through epidermis } \\
\text { lled persistent probasidia } \\
\text { paraphyses } \\
\text { globose }\end{array}$ & $\begin{array}{l}\text { "Dicellomy } \\
\text { hosts } \\
\text { - Cyperaceae } \\
\text { basidia } \\
\text { - in gelatinous } \\
\text { breaking throu } \\
\text { - swollen, not } \\
\text { - with paraphy } \\
\text { conidia - allan }\end{array}$ & $\begin{array}{l}\text { cirpi (1 sp.) } \\
\text { carps } \\
\text { ermis } \\
\text { nt probasidia }\end{array}$ & $\begin{array}{l}\text { Exobasidiellum (1 species) } \\
\text { hosts } \\
\text { - Poaceae } \\
\text { basidia } \\
\text { - in a layer on the surface of host } \\
\text { tissue } \\
\text { - without paraphyses } \\
\text { - with probasidial swellings } \\
\text { conidia - ovoid }\end{array}$ \\
\hline $\begin{array}{l}\text { Kordyana ( } 7+3 \text { doubtful species) } \\
\text { hosts } \\
\text { - Commelinaceae (Bignoniaceae, } \\
\text { Burseraceae, Poaceae) } \\
\text { basidia } \\
\text { - in suprastomatal balls } \\
\text { - sometimes with paraphyses } \\
\text { - some species with probasidial } \\
\text { sacs in substomatal chambers } \\
\text { conidia } \\
\text { - fusiform, globose, or subpyriform }\end{array}$ & $\begin{array}{l}\text { basi } \\
\text { - in } 5 \\
\text { - with } \\
\text { - with } \\
\text { subs } \\
\text { coni }\end{array}$ & $\begin{array}{l}\text { astomatal balls } \\
\text { raphyses } \\
\text { basidial sacs in } \\
\text { atal chambers } \\
\text { - fusiform }\end{array}$ & $\begin{array}{l}\text { Meira (6 spe } \\
\text { substrates } \\
\text { - isolated from } \\
\text { - saprotrophic } \\
\text { basidia } \\
\text { - absent (asex } \\
\text { conidia } \\
\text { - fusiform }\end{array}$ & Is substrates & $\begin{array}{l}\text { Proliferobasidium (1 species) } \\
\text { hosts } \\
\text { - Heliconiaceae } \\
\text { basidia } \\
\text { - in gelatinous pustules breaking } \\
\text { through epidermis or stomata } \\
\text { - with thick-walled probasidia } \\
\text { - without paraphyses } \\
\text { - with repeated proliferation from } \\
\text { within the probasidial wall } \\
\text { conidia - globose }\end{array}$ \\
\hline
\end{tabular}

orders, for families of Exobasidiales, and for genera of Brachybasidiaceae are summarized in Table 1, following the way of presentation used by de Beer et al. (2006) for
Microstromatales. For species included in the genera of Brachybasidiaceae, host species, and known geographic distribution, see Online Resource 1. Selected species of 
a

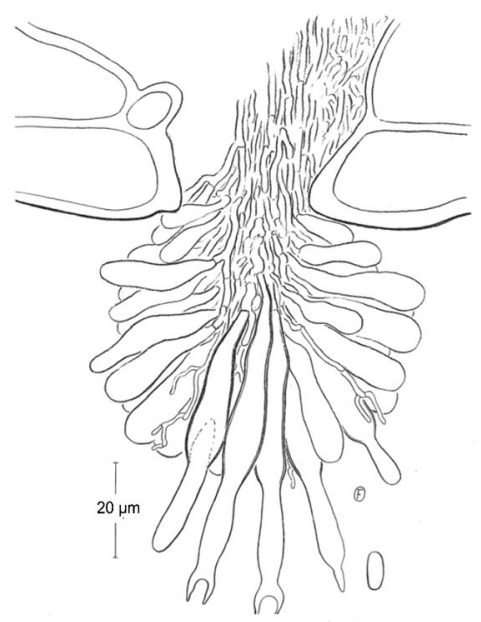

C

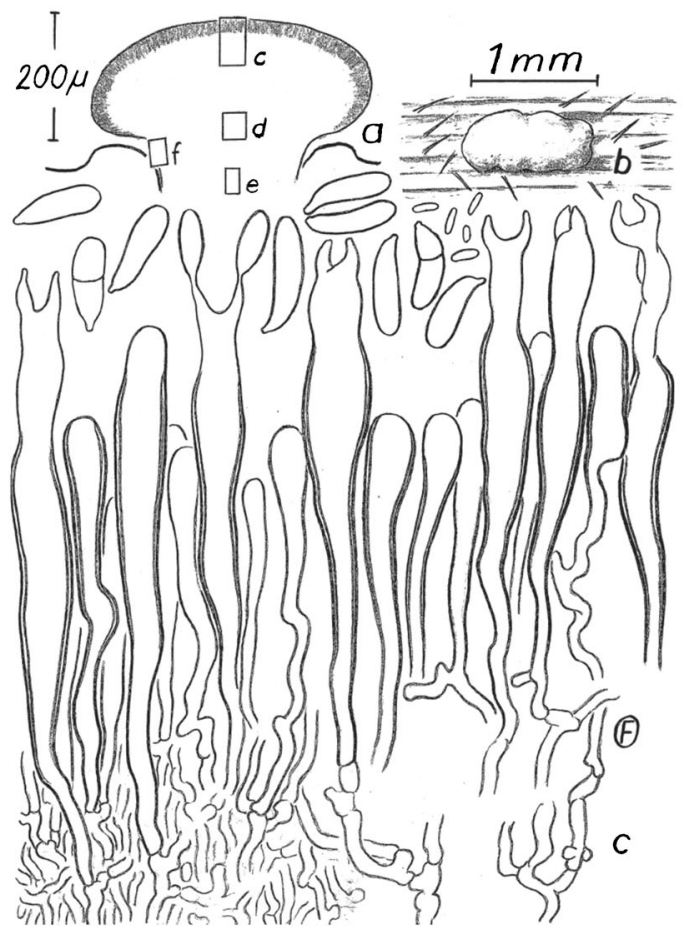

d

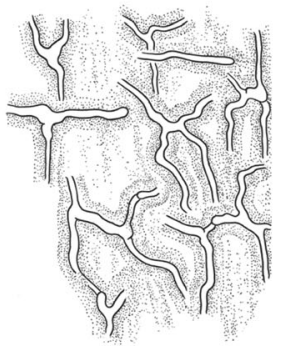

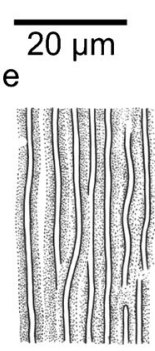

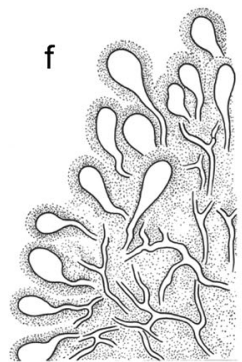

Fig. 1 Original line drawings by Franz Oberwinkler of selected species of Brachybasidiaceae (included with the approval by Barbara Oberwinkler). a Brachybasidium pinangae (comp. Fig. 13 in Begerow et al. 2002). Ball of basidia with probasidia on top of a stomatal opening. b Exobasidiellum graminicola (comp. Fig. 14 in Begerow et al. 2002). Basidia with thickwalled probasidia forming a layer on host tissue as well as just liberated and germinating basidiospores with conidia. $\mathbf{c}$ Dicellomyces gloeosporus.

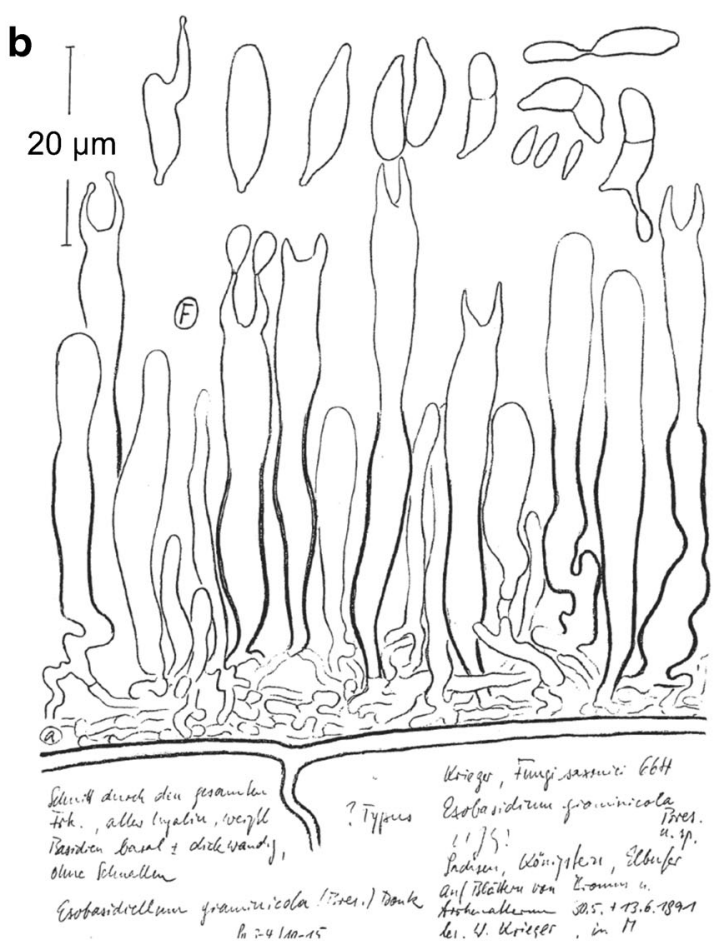

d
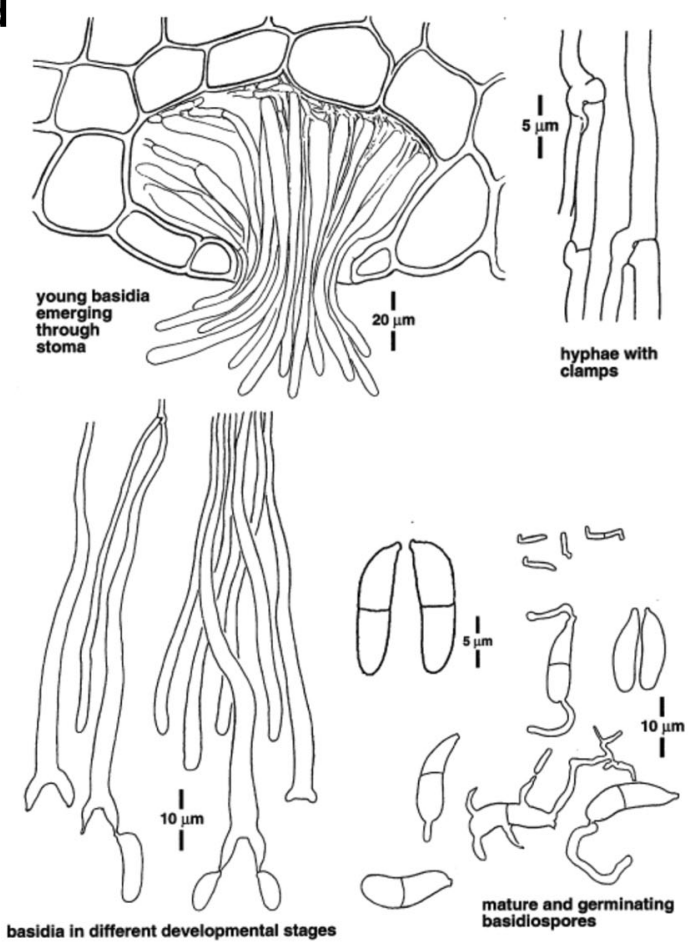

For localizations of drawings labeled with non-bold letters c-f see sketch at non-bold a. (a) Schematically drawn longitudinal section of a basidiocarp. (b) Gelatinous basidiocarp on host tissue. (c) Basidia with probasidial thickenings, basidiospores, and conidia. (d) Hyphae in a gelatinous matrix. (e) Parallel hyphae in the base of the basidiocarp. (f) Hyphae with swollen tips at the lower surface of the basidiocarp. d Kordyana tradescantiae (comp. Fig. 15 in Begerow et al. 2002) 
Brachybasidiaceae are illustrated by drawings elaborated by Franz Oberwinkler (Fig. 1).

The taxonomic history of the group of fungi currently classified in Brachybasidiaceae started in 1892 when Patouillard and von Lagerheim (1892) described Exobasidium tradescantiae Pat. (now Kordyana tradescantiae (Pat.) Racib.) based on a fungus infecting a species of Tradescantia (Commelinaceae) from Ecuador, and when Bresadola (in Krieger, Fung. Saxon. Exsicc., Pilze Sachsen's: no. 664, 1892) presented the species Exobasidium graminicola Bres. (now Exobasidiellum graminicola (Bres.) Donk) on Poaceae (Online Resource 1). The oldest genus currently placed in Brachybasidiaceae is Kordyana, established by Raciborski in 1900 including Kordyana pinangae Racib. (now Brachybasidium pinangae (Racib.) Gäum.) and Kordyana tradescantiae that was selected as type species by Gäumann (1922). Gäumann (1922) created the genus Brachybasidium with B. pinangae as type species and established the family Brachybasidiaceae in 1926 (Gäumann 1926). Further genera currently placed in Brachybasidiaceae are Exobasidiellum (Donk 1931), Dicellomyces (Olive 1945), Proliferobasidium (Cunningham et al. 1976), and Meira (Boekhout et al. 2003), with the latter including up to now only asexually multiplying yeasts.

The genus Dicellomyces with the type species D. gloeosporus L.S. Olive on a species of Poaceae has been used to classify four species of plant-parasitic fungi forming gelatinous, pustulate basidiocarps breaking through the host tissue. Dicellomyces bombacis B.K. Bakshi infecting a species of Malvaceae, however, was separated from other Dicellomyces spp. as Ceraceosorus bombacis (B.K. Bakshi) B.K. Bakshi first within the Brachybasidiaceae (Cunningham et al. 1976) and later in the order Ceraceosorales based on molecular sequence data (Begerow et al. 2006; Piątek et al. 2016).

Raciborski (1900) described a further genus called Lelum based on Lelum ustilaginoides Racib. on Persea sp., which is attributed to Brachybasidiaceae by some authors (e.g., Kirk 2019). However, due to the host species belonging to Lauraceae, a light brown spore mass, and basidiospores with longitudinal ridges, we suppose that this species may belong to Cryptobasidiaceae. Though basidia carry two basidiospores each, this characteristic does not fit to the morphological concept of Cryptobasidiaceae. Thus, this species needs further analyses.

The authors contributing to the knowledge of Brachybasidiaceae in the past noticed similarities of the species included in Brachybasidiaceae and Exobasidiaceae, but they also noted important differences, especially the fact that species of Brachybasidiaceae develop basidia with only two sterigmata each, in contrast to basidia of typical species of Exobasidiales that develop mostly 4 (2-8) basidiospores.
Basidiospores of Exobasidium spp. further differ from basidiospores of species of Brachybasidiaceae by apiculi with abaxial orientation. Forked basidia with two basidiospores that develop septa during germination are typical for species of Brachybasidiaceae and for species of Dacrymycetales (Agaricomycotina). The sterigmata of dacrymycetalean basidia, however, are much longer than those of the species of Brachybasidiaceae, and species of Dacrymycetales are saprotrophs in contrast to species of Brachybasidiaceae that are exclusively plant-parasitic during their sexual development (Oberwinkler 1982).

In the working group of Franz Oberwinkler, R. Bauer, D. Begerow, and F. Oberwinkler himself made important contributions to the systematics of Ustilaginomycotina at order and family level. On genus and species level, however, our knowledge of Brachybasidiaceae is still very incomplete, as evident by incomplete morphological descriptions, several taxonomic problems, and molecular sequences lacking for most described species in this group (comp. Begerow et al. 2018; Berndt and Sharma 1998). By the present publication, we contribute new data to this group based on recently collected specimens from Bolivia and Panama in the neotropics.

\section{Materials and methods}

\section{Specimens}

The specimens of Brachybasidiaceae cited in this study were collected during fieldwork for research and teaching. The new species from Panama was first noticed in the context of the Majagua project (M numbers, Piepenbring et al. 2012b). The new species collected in Bolivia was found during the "Curso de hongos" ( $\mathrm{CH}$, Course on Fungi), realized at the Universidad Autónoma Gabriel René Moreno in Santa Cruz, Bolivia. The specimens were analyzed, preserved, and deposited in the herbarium of the Universidad Autónoma de Chiriquí, Panama (UCH), the national herbarium of the Universidad de Panamá (PMA), in the herbarium of the Museo de Historia Natural Noël Kempff Mercado at the Universidad Autónoma Gabriel René Moreno, Bolivia (USZ), and/or in the Botanische Staatssammlung München, Germany (M).

\section{Identification of host plants}

The host plant species of the specimen collected in Panama was identified as Goeppertia panamensis (Rowlee) Borchs. \& S. Suárez (syn. Calathea panamensis Rowlee, Marantaceae) based on keys and descriptions in the Flora of Panama (Woodson and Schery 1943) and herbarium specimens deposited in PMA. 
The host plant of the specimen from Bolivia has been identified with the help of the checklist of plants for Bolivia (Jørgensen et al. 2014), diverse Florae (Costa Rica: Hammel et al. 2003; Panama: Woodson and Schery 1943), molecular sequence data of the ITS region and of the rbcL gene, and labeled photos available on the Internet.

In order to obtain DNA sequence data, the following primers have been used: for the ITS region, ITS5A-F (Stanford et al. 2000) and 241r-R (Michelangeli et al. 2004) and for the rbcLa marker, the primers rbcLa-F (SI-For) and rbcLa-R (SI-Rev) (Kress et al. 2009).

The ITS sequence (GenBank acc. no. MN399972) obtained from the host plant from Bolivia shows identities of $97 \%$ and more with several species of Goeppertia (Calathea). Among these species, the only one that is reported for Bolivia and morphologically similar to the specimen collected in Bolivia is Goeppertia propinqua (Poepp. \& Endl.) Borchs. \& S. Suárez, that is represented by the sequence JQ341297 (published by Borchsenius et al. 2012) in GenBank and has 97\% percent identity with the sequence from the plant from Bolivia. For the rbcL sequence (GenBank acc. no. MN953612), there is no sequence of Goeppertia propinqua available in GenBank for comparison.

\section{Morphological analysis}

Fresh and dried specimens of recently collected Brachybasidiaceae were investigated morphologically following standard methods as described by Judith et al. (2015). Measurements represent mean values plus/minus standard deviation and minimum and maximum values are given in parentheses. Hyphae, basidia, basidiospores, and conidia of these fungi are relatively small and thin-walled. They easily collapse when dried. Therefore, preferably fresh specimens were analyzed or sections were made by hand with new razor blades from fresh sori. These sections were preserved on glass slides below cover slips in a mounting medium for semipermanent preparations with cotton blue.

\section{Molecular analysis of the fungi}

\section{DNA extraction, PCR, and sequencing}

Genomic DNA was isolated directly from the herbarium specimens. Isolation of fungal material, DNA extraction, amplification, purification of PCR products, and sequencing were provided by the ALVALAB, Oviedo, Spain. For some specimens, this was done with innuPREP Plant DNA Kit (Analytikjena, Jena, Germany) and sequences were obtained from Microsynth Seqlab (Göttingen, Germany). The ITS15.8S-ITS2 region of the ribosomal DNA (ITS) was amplified using the primer pair ITS1-F (Gardes and Bruns 1993) and ITS4 (White et al. 1990). The 5'-end of the nuclear large subunit ribosomal DNA (LSU) was amplified using the primer pair LR0R and LR5 (White et al. 1990; O'Donnel 1992, 1993). The DNA sequences determined for this study were deposited in GenBank (GenBank accession numbers are given in Fig. 2 and the taxonomy section).

\section{Phylogenetic analyses}

To elucidate the phylogenetic position of the specimens from Bolivia and Panama, their sequences were analyzed within a concatenated ITS + LSU dataset. Since preliminary analyses and the comparison of the sequences to available data in GenBank using BLAST (Altschul et al. 1997) revealed an affinity of the specimens to the Exobasidiales, the dataset was reduced to members of the Exobasidiales and Rhamphospora nymphaeae (Doassansiales) as outgroup. The dataset covered all Exobasidiales genera of which sequences were available in GenBank. If present in GenBank, sequences of the respective type species were used. In addition, sequences of all available species of Brachybasidiaceae and Graphiolaceae were added including sequences from the public catalog of the NITE Biological Resource Center collection (NBRC), Japan. GenBank accession numbers of the sequences used (Begerow et al. 2002; Boekhout et al. 2003; Cao et al. 2018; Crous et al. 2003; Kottke et al. 2010; Kruse et al. 2017; Macedo et al. 2016; Maier et al. 2006; Matheny et al. 2006; Nasr et al. 2019; Piepenbring et al. 2010, 2012a; Schoch et al. 2014; Sepúlveda et al. 2017; Tanaka et al. 2008; Wang et al. 2015; Yasuda et al. 2005) are cited in Fig. 2.

Sequence alignment was obtained independently for the ITS and LSU part of the ITS + LSU dataset using MAFFT 7.313 (Katoh and Standley 2013) with the L-INS-i option. To obtain reproducible results, manipulation of the alignments by hand as well as manual exclusion of ambiguous sites were avoided as suggested by Gatesy et al. (1993) and Giribet and Wheeler (1999). Instead, highly divergent portions of the alignments were omitted using GBlocks $0.91 \mathrm{~b}$ (Castresana 2000) with the following options for the ITS part of the ITS + LSU dataset: "Minimum Number of Sequences for a Conserved Position": 9, "Minimum Number of Sequences for a Flank Position": 9, "Maximum Number of Contiguous Non-conserved Positions": 8, "Minimum Length of a Block": 5, and "Allowed Gap Positions" to "With half." For the LSU part of the ITS + LSU dataset, these parameters were set to 14/ $14 / 11 / 5 /$ "With half," respectively. Afterwards, the ITS and LSU sequence alignments were concatenated.

The resulting alignment (new number of positions, 1099 ( $23 \%$ of the original 4783 positions); number of variable sites, 543) was used for phylogenetic analyses applying Bayesian inference (BI) and maximum likelihood (ML). For the BI analysis, a Markov chain Monte Carlo technique was used as implemented in MrBayes 3.2.6 (Ronquist et al. 2012). Two runs over 5,000,000 generations, each consisting of four 
Fig. 2 Bayesian inference of phylogenetic relationships among the sampled Exobasidiales. Markov chain Monte Carlo analysis of an alignment of concatenated ITS + LSU sequences using the GTR $+\mathrm{I}+\mathrm{G}$ model of DNA substitution with gamma-distributed substitution rates and an estimated proportion of invariant sites, random starting trees, and default starting parameters of the DNA substitution model. A 50\% majority-rule consensus tree is shown computed from 75,000 trees that were sampled after the process had become stationary. The topology was rooted with Rhamphospora nymphaeae (Doassansiales). Numbers on branches before slashes are estimates for a posteriori probabilities; numbers on branches after slashes are ML bootstrap support values. Branch lengths were averaged over the sampled trees. They are scaled in terms of expected numbers of nucleotide substitutions per site. The applied taxonomical concepts follow Begerow et al. (2014). Species belonging to the new genus are indicated in bold

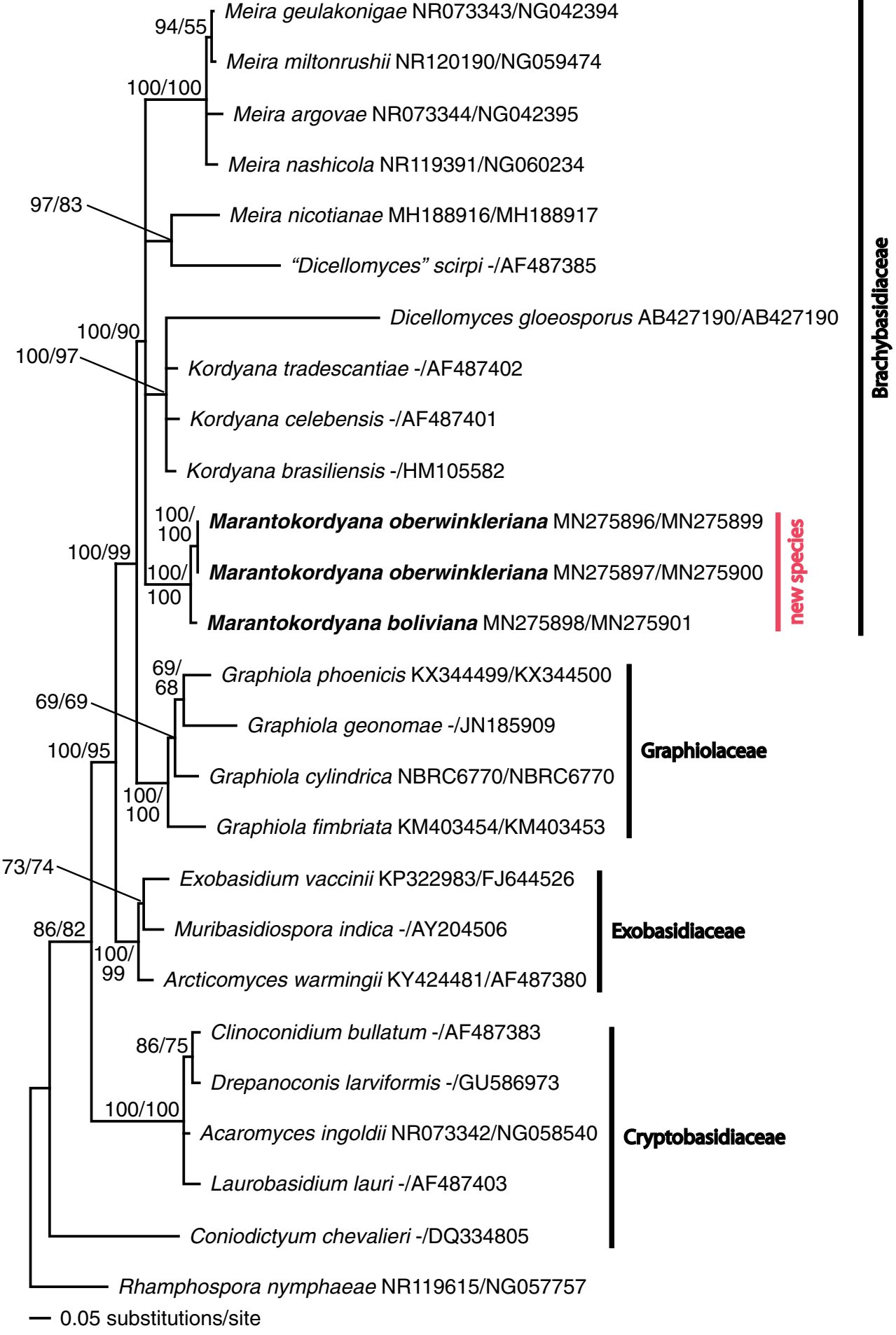

chains, were implemented using the general time-reversible model of DNA substitution with gamma-distributed substitution rates and estimation of invariant sites, random starting trees, and default starting parameters of the DNA substitution model as recommended by Huelsenbeck and Rannala (2004). Trees were sampled every 100th generation, resulting in a sampling of 50,001 trees for each run. From these, the first
$25 \%$ of trees from each run were discarded (burn-in). The remaining trees were used to compute a $50 \%$ majority-rule consensus tree to obtain estimates for the a posteriori probabilities of groups of species. This Bayesian approach to phylogenetic analysis was repeated five times to test the independence of the results from topological priors (Huelsenbeck et al. 2002). ML analysis (Felsenstein 1981) was conducted 
with RAxML 8.2.11 (Stamatakis 2014) invoking the GTRGAMMA and the rapid bootstrap option (Stamatakis et al. 2008) with 1000 replicates, but omitting an estimated proportion of invariant sites following the advice given in the user manual (Stamatakis 2016).

\section{Results}

\section{Phylogenetic analyses}

For the two specimens of Brachybasidiaceae on Goeppertia panamensis from two localities in Panama, the ITS and LSU sequences were identical, while the sequences obtained from the specimen collected in Bolivia on Goeppertia propinqua differed in $36 \mathrm{bp} / 6.4 \%$ for the ITS region and $32 \mathrm{bp} / 2.6 \%$ for the LSU.

The different runs of the BI and the ML analysis yielded consistent topologies. To illustrate the results, the consensus tree of one run of the BI is presented (Fig. 2). Using Rhamphospora nymphaeae as outgroup, the clades in the phylogenetic tree were congruent to the families as presented by Begerow et al. (2014). In all analyses, the specimens from Bolivia and Panama formed a strongly supported monophylum in a well-supported group including all sequences from Dicellomyces, Kordyana, and Meira specimens.
However, relations between these taxa were not resolved. Species of Kordyana formed a monophylum together with Dicellomyces gloeosporus and Dicellomyces as well as Meira were revealed to be polyphyletic.

\section{Taxonomy}

Marantokordyana M. Piepenbr., Maike Hartmann, T.A. Hofm. \& M. Lutz, gen. nov. (MycoBank number MB 832383)

Type species: Marantokordyana oberwinkleriana M. Piepenbr., Maike Hartmann, T.A. Hofm. \& M. Lutz, see below

Etymology: The name refers to morphologically similar species of Kordyana and to the host family Marantaceae.

\section{Description:}

Plant-parasitic fungi infecting species of Marantaceae. Fungal hyphae in intercellular spaces in leaves, causing yellowish spots without hypertrophic growth, filling substomatal chambers, protruding through stomatal openings. Basidia exposed on top of stomata on the abaxial side of leaf blades in spherical balls, mixed with paraphyses, each basidium with two straight sterigmata carrying one basidiospore each. Basidiospores blastosporic, with conspicuous hilum, without apiculus, cylindrical to slightly allantoid, often liberated in pairs, with one central septum at maturity. Basidiospores germinating with thin hyphae producing tiny, rod-shaped to
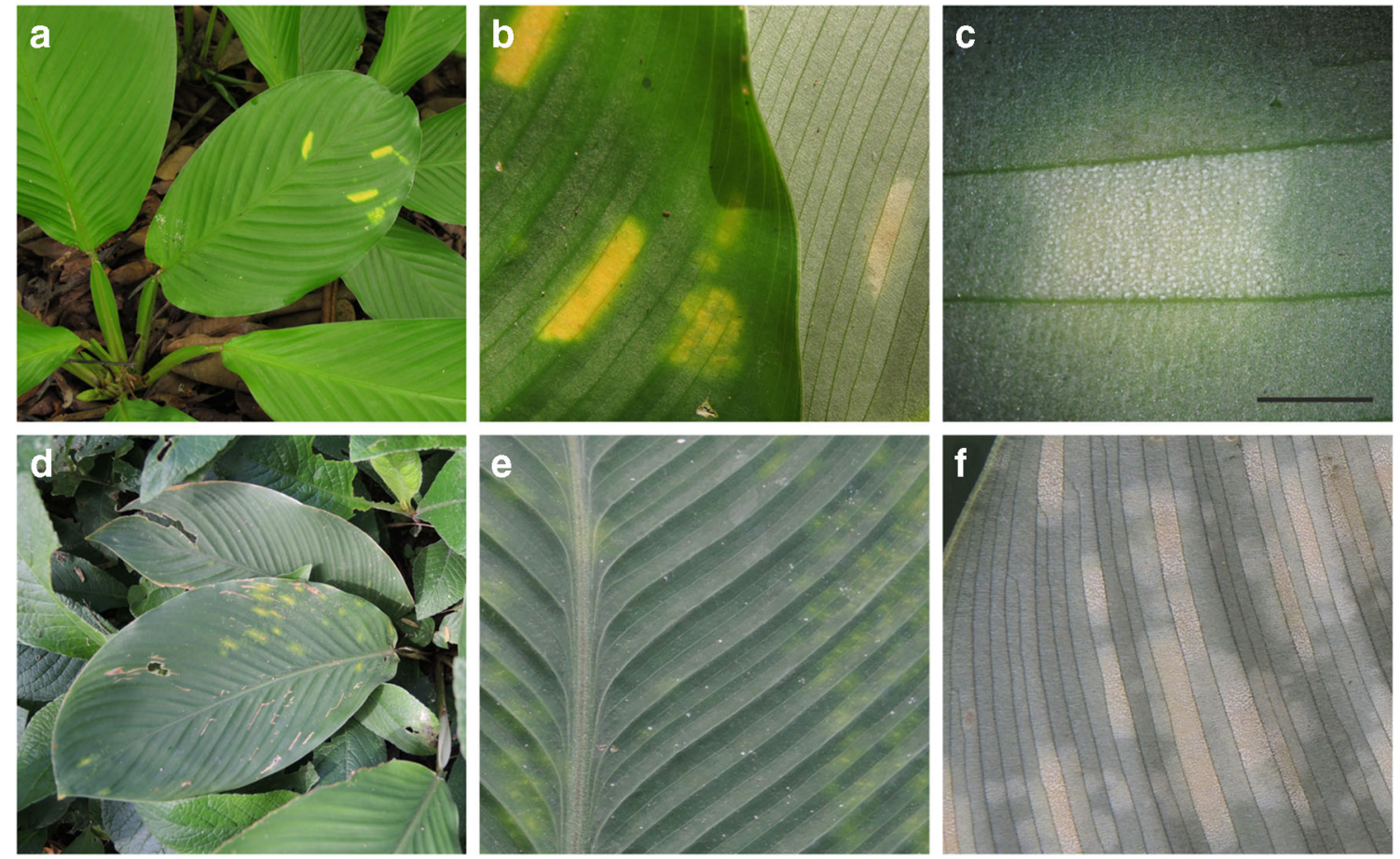

Fig. 3 Species of Marantokordyana. a-c M. oberwinkleriana on Goeppertia panamensis (MP 5127). a Infected plant in the field. b The upper side and the lower side of leaf blades with leaf spots. c A leaf spot seen from the lower side of the blade by a stereomicroscope. Each white

dot is a ball of basidia. Scale bar $=2 \mathrm{~mm}$. $\mathbf{d}-\mathbf{f}$ M. boliviana on Goeppertia propinqua (CH 11). d Infected plant in the field. $\mathbf{e}$ The upper side of a leaf blade with leaf spots. $\mathbf{f}$ Leaf spots seen from the lower side of the blade. White dots are balls of basidia 
Fig. 4 Marantokordyana oberwinkleriana on Goeppertia panamensis (MP 5412, holotype). a Transverse section of a leaf showing abaxial mesophyll, the abaxial epidermis, substomatal chamber filled with fungal cells (stroma), and a ball of paraphyses and basidia that liberated basidiospores single or in pairs. $\mathbf{b}$ Transverse section of a leaf showing abaxial mesophyll, the abaxial epidermis, and a substomatal chamber without fungal cells. Scale bars $=10 \mu \mathrm{m}$

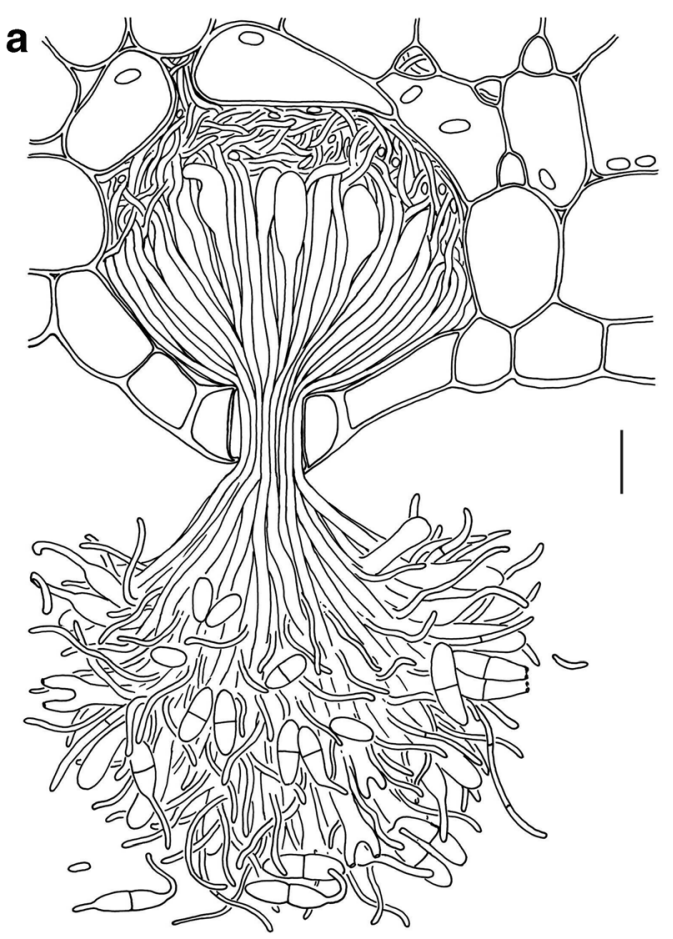

b

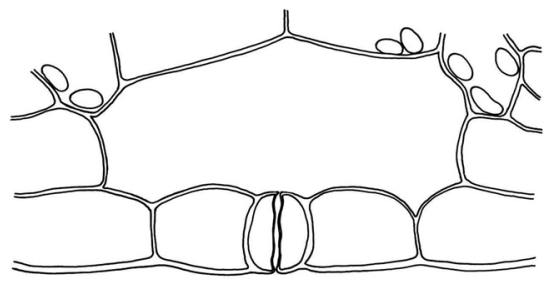

fusiform conidia that multiply by budding yeast cells.

Marantokordyana oberwinkleriana M. Piepenbr., Maike Hartmann, T.A. Hofm. \& M. Lutz, sp. nov. (MycoBank number MB 832384) (Figs. 3a-c, 4, and 5)

Type on Goeppertia panamensis (Rowlee) Borchs. \& S. Suárez (syn. Calathea panamensis Rowlee; Marantaceae). Panama, Chiriquí province, Dolega district, Los Algarrobos, trail to Río Majagua, $8^{\circ} 29^{\prime} 22^{\prime \prime} \mathrm{N}, 82^{\circ} 26^{\prime} 1^{\prime \prime} \mathrm{W}, 110 \mathrm{~m}$ asl., 10. 8. 2018, leg. M. Piepenbring and M.U. Schmidt MP 5412 (holotype PMA 0123802, isotypes M 141363, UCH 11709). GenBank: ITS $=$ MN275897, LSU $=$ MN275900.

Etymology: This species is named in honor of Franz Oberwinkler (1939-2018) who made important contributions to the knowledge of heterobasidiomycetes (comp. Piepenbring et al. 2019).

\section{Description:}

Leaf blades with scattered to numerous spots due to infection. Infected areas elongated rectangular and rounded at the ends, laterally delimited by veins of the leaf blade, not swollen, in surface view mostly $(3-) 4-10(-11) \times(1.5-) 2-$ $2.5(-3) \mathrm{mm}(n=10)$, sometimes larger by fusion, adaxially yellow to slightly orange colored, abaxially white surrounded by a ring of tissue of yellowish color, with white balls of basidia evident with a hand lens or a stereomicroscope. All the substomatal chambers of an infected area filled by fungal hyphae in dense stromata, hyphae protruding through the stomatal openings, developing balls of basidia mixed with paraphyses, one ball on the top of each stoma, balls of basidia easily breaking off and being dispersed.
Substomatal chambers filled with fungal stroma formed by dense fungal hyphae, more voluminous than substomatal chambers without fungal stroma (Fig. 4), cellular details of fungal stroma difficult to distinguish, in very thin sections three types of fungal hyphae distinguishable, very thin (approx. $1 \mu \mathrm{m}$ wide) hyphae close to host cells, thin (approx. $1.5 \mu \mathrm{m}$ wide) hyphae mixed with the thick hyphae, and thick (approx. $3 \mu \mathrm{m}$ wide) hyphae with swellings of up to $5 \mu \mathrm{m}$ width at the base.

Balls of basidia spherical to globose, composed of basidia in different developmental stages and $1.5 \mu \mathrm{m}$ wide paraphyses densely packed in the center and loosely exposed at the surface of a ball, $(40-) 55-80(-90) \mu \mathrm{m}$ diam. $(n=20)$, not pigmented.

Basidia holobasidia, with basidial cell cylindrical, of variable length of up to at least $70 \mu \mathrm{m}$, sometimes shorter by retraction septa formed during sporulation, 3-4(-4.5) $\mu \mathrm{m}$ wide $(n=10)$, thinner after the liberation of the basidiospores, with two apical, straight or bent, elongated and often slightly swollen sterigmata of $(2-) 3.5-6.5(-7.5) \times 1.5-2 \mu \mathrm{m}(n=20)$, with one basidiospore developing at the tip of each sterigma. After liberation of the basidiospores basidial cells empty, sometimes with scattered tiny remnants of cytoplasm, with scars evident at the tips of the sterigmata.

Basidiospores liberated singly or in pairs, at the moment of liberation one-celled but soon afterwards two-celled due to a central septum, cylindrical or slightly allantoid and slightly fusoid at the base, with a conspicuous hilum (scar) at the base of each basidiospore, $(10-) 11-16(-19) \times 3-4.5(-6) \mu \mathrm{m}(n=$ 
Fig. 5 Marantokordyana oberwinkleriana (M 409, MP 5127). a Tips of young and sporulating basidia. b Tip of a paraphysis of a ball of basidia. c Basidiospores single or in pairs. d Two basidiospores connected by a conjugation bridge at their bases. e Tips of basidia after liberation of basidiospores. $\mathbf{f}$ Germinating basidiospores. $\mathbf{g}$ Conidia budding as yeasts. Scale bars $=10 \mu \mathrm{m}$
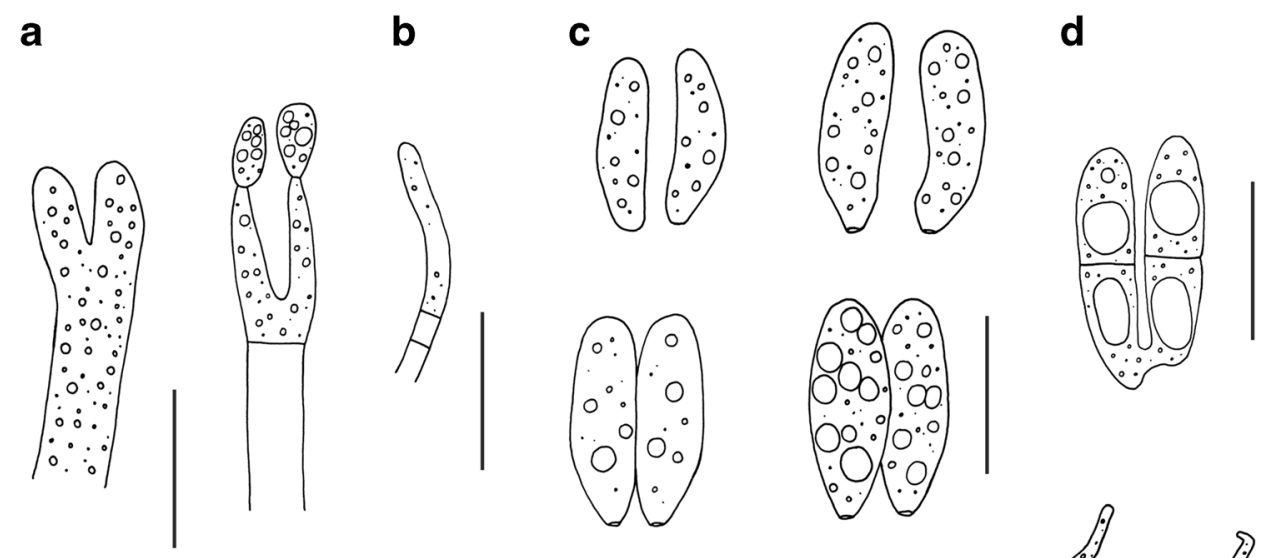

e
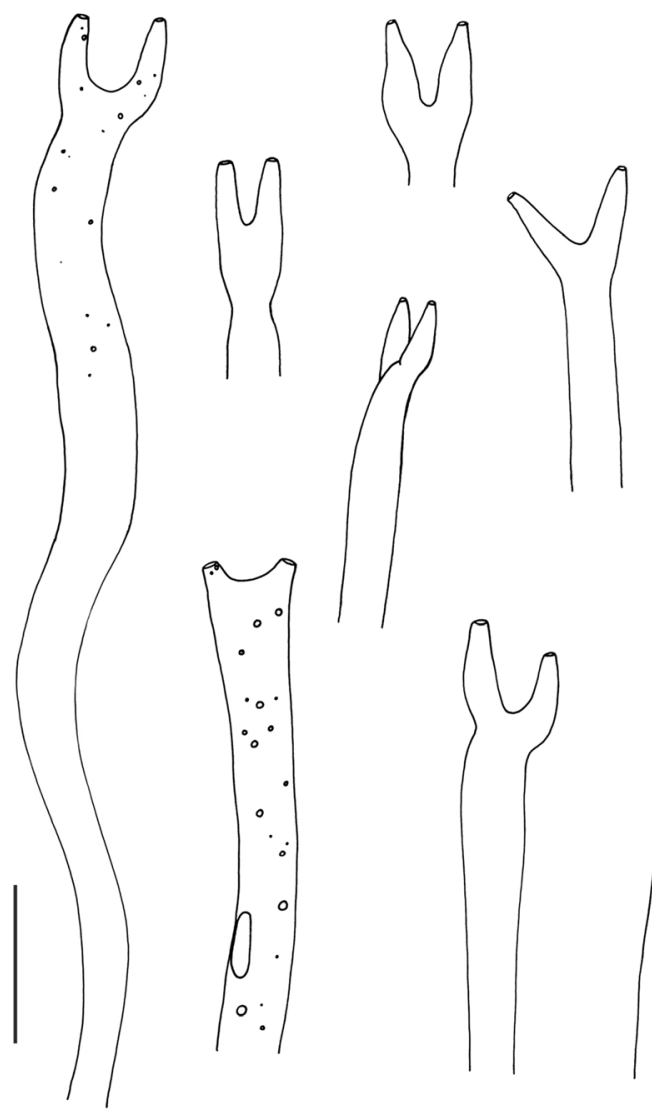

f
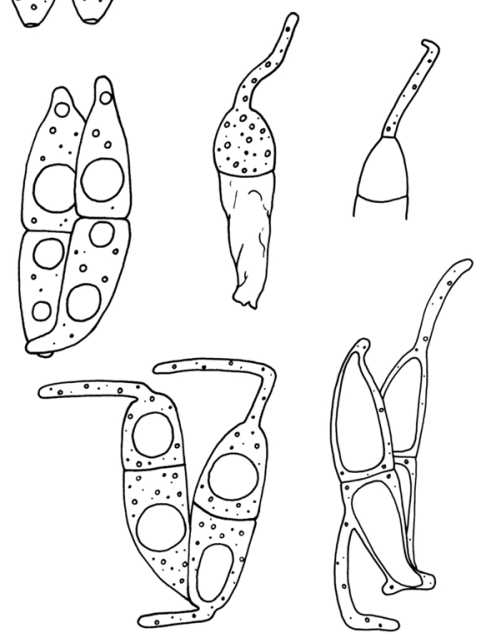

g

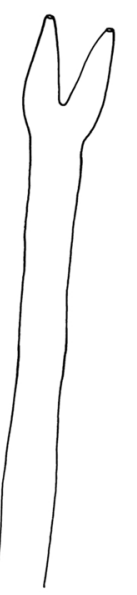

30), hyaline, smooth, densely filled with oil drops or with homogeneous cytoplasm. The two basidiospores of one basidium conjugating by fusing or individual basidiospores germinating with about $1 \mu \mathrm{m}$ wide hyphae originating at their tips or laterally and developing conidia on more or less evident sterigma-like outgrowths or cells of basidiospores directly developing conidia usually at their tips.

Conidia mostly one-celled, rarely with septum, rod-shaped to fusiform or slightly allantoid, with scar at the point of detachment, 3-8(-11) $\times(0.5-) 1(-1.5) \mu \mathrm{m}(n=20)$, hyaline, smooth, germinating with thin hyphae or budding forming further conidia (yeast cells).

Further specimens examined: On Goeppertia panamensis. Panama, Chiriquí province, locality of the type, 12. 8. 2009, leg. M. Piepenbring and T.A. Hofmann M 409 (M 141366, UCH 11710). Same locality, 31. 8. 2009, leg. M. Piepenbring and T.A. Hofmann M 504 (M 141365, UCH 11711). Almost the same locality, $8^{\circ} 29^{\prime} 18^{\prime \prime} \mathrm{N}, 82^{\circ} 26^{\prime} 2^{\prime \prime} \mathrm{W}, 107 \mathrm{~m}$ asl., 27. 7. 2012, leg. M. Piepenbring and A. Krohn MP 5127 (M 141364, PMA 
0123801). Panama, Chiriquí province, Gualaca district, close to Gualaca, canjilones de Gualaca, $8^{\circ} 33^{\prime} 0.53^{\prime \prime} \mathrm{N}$, $82^{\circ} 18^{\prime} 3.44^{\prime \prime} \mathrm{W}, 133 \mathrm{~m}$ asl., 29. 7. 2018, leg. M. Piepenbring, N. Avila, R. Duarte, and M.U. Schmidt MP $5402(\mathrm{UCH}$ 11712; GenBank: ITS $=$ MN275896, LSU $=$ MN275899).

Marantokordyana boliviana $\mathrm{M}$. Piepenbr., Maike Hartmann, M. Lutz \& T.A. Hofm., sp. nov. (MycoBank number MB 832385) (Figs. 3d-f and 6)

Type on Goeppertia propinqua (Poepp. \& Endl.) Borchs. \& S. Suárez (syn. Calathea propinqua (Poepp. \& Endl.) Körn.; Marantaceae). Bolivia, Department of Santa Cruz,
Andrés Ibañez Province, Municipio Porongo, Terebinto, Hacienda Privada Arubai, $17^{\circ} 41^{\prime} 10^{\prime \prime} \mathrm{S}, 63^{\circ} 25^{\prime} 15^{\prime \prime} \mathrm{E}$, $448 \mathrm{~m}$ asl., 13. 2. 2019, M. Piepenbring and participants of the Curso de Hongos CH 88 (holotype USZ). GenBank: ITS $=$ MN275898, LSU $=$ MN275901.

Etymology: The type of this species was discovered in Bolivia.

\section{Description:}

Leaf blades with scattered to sometimes very numerous spots due to infection. Infected areas elongated rectangular and often poorly delimited, on the abaxial side laterally delimited by veins of the leafblade, notswollen, on the abaxial side intercostal areas with balls of basidia mostly (6-)7-

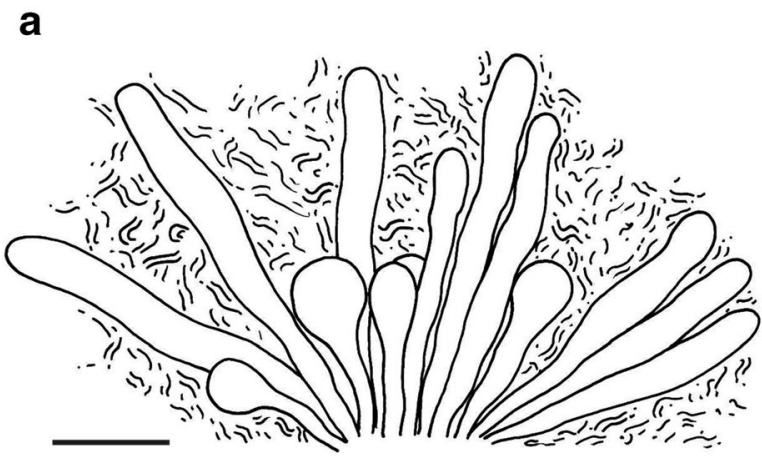

b

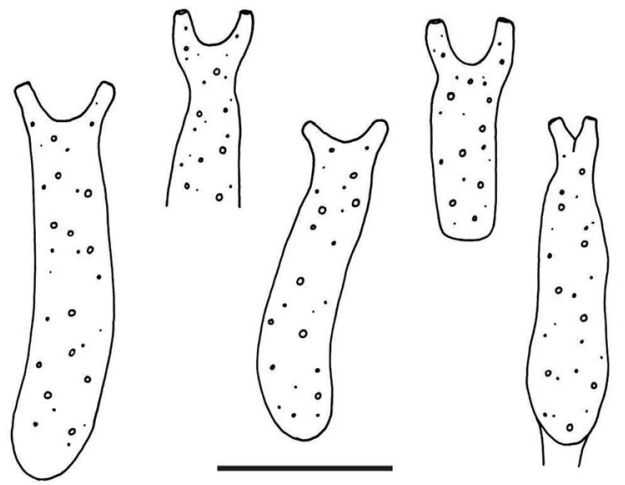

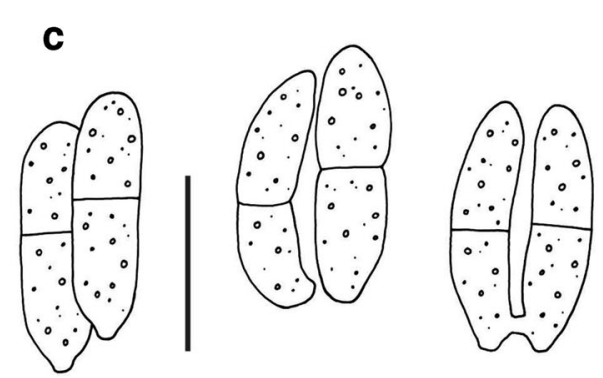
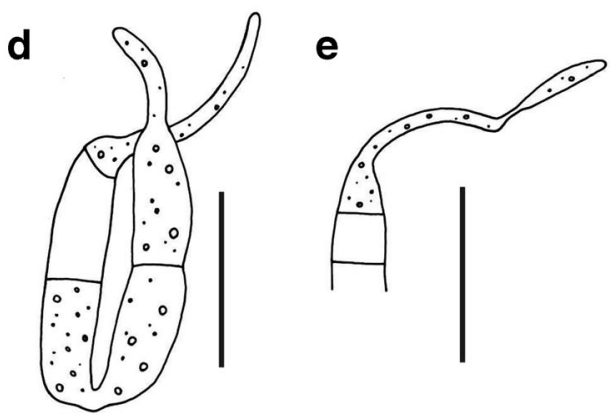

Fig. 6 Marantokordyana boliviana (CH 88). a Fungal cells isolated from a substomatal chamber, without adjacent host cells. Thick hyphae with probasidial swellings directed towards the stomatal opening (not shown) and thin, indistinguishable hyphae filling the space in between. $\mathbf{b}$ Basidia after the liberation of basidiospores. $\mathbf{c}$ Liberated basidiospores in pairs, one pair with a conjugation bridge at the base. d Conjugated basidiospores germinating with hyphae. Note the retraction septum in

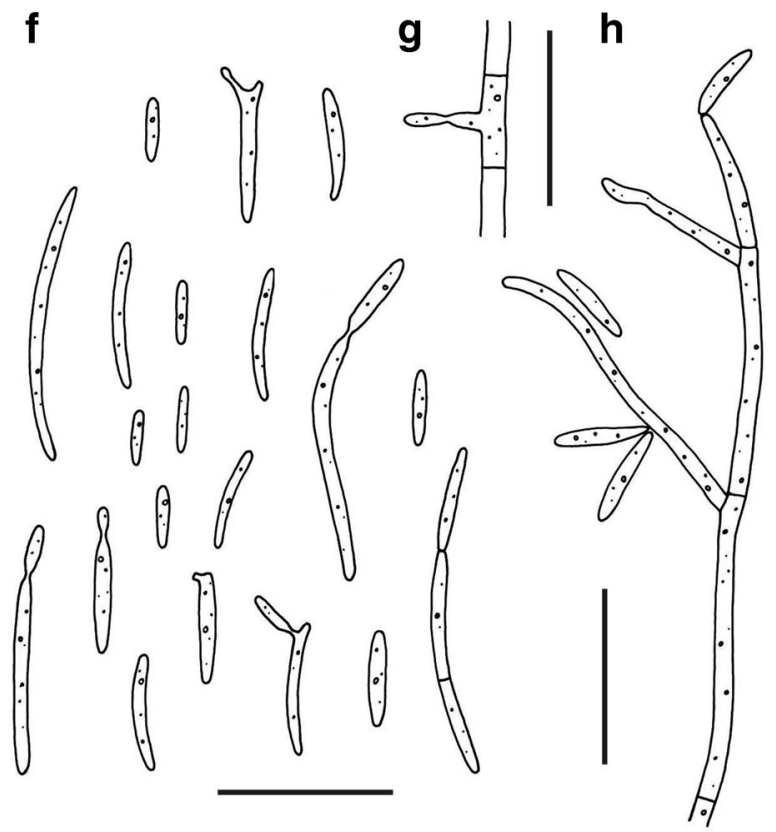

the cell on the left hand side. e One half of a basidiospore forming a conidium at the tip of a hypha. Note the retraction septum. $\mathbf{f}$ Yeast-like conidia budding or forming conidia on sterigma-like outgrowths. g An intercalary cell of a hypha with an outgrowth developing a conidium. h A hypha developing conidia. Septa of the hypha are difficult to distinguish. Scale bars $=10 \mu \mathrm{m}$ 
$14(-15) \times 1.5-2 \mathrm{~mm}(n=10)$, probably older infected areas much larger by fusion of leaf spots, adaxially yellowish, abaxially whitish to slightly yellow to orange colored areas of sporulation surrounded by whitish host tissue, with white balls of basidia evident with a hand lens or a stereomicroscope. All the substomatal chambers of an infected area filled by fungal hyphae in dense stromata, hyphae protruding through the stomatal openings, developing balls of basidia mixed with paraphyses, one ball on the top of each stoma, balls of basidia easily breaking off and being dispersed.

Substomatal chambers filled with fungal stroma formed by dense fungal hyphae, cellular details of fungal stroma difficult to distinguish, in the stroma isolated from a substomatal chamber two types of fungal hyphae distinguishable, thick hyphae that penetrate through the stoma and develop basidia outside the host tissue and thin hyphae that fill the space between the thick hyphae. Thick hyphae mostly about $4 \mu \mathrm{m}$ wide, cylindrical with more or less undulated walls or thinner and sometimes with a basal, probably probasidial swelling of 4-6 $\mu \mathrm{m}$ width at their base. Thin hyphae about $1 \mu \mathrm{m}$ wide, curled, ramified, very difficult to distinguish by light microscopy.

Balls of basidia globose or of irregular shape, composed of basidia of different ages and approx. $1 \mu \mathrm{m}$ wide paraphyses densely packed in the center and loosely exposed at the surface of a ball, (60-)70-90(-100) $\mu \mathrm{m}$ diam. $(n=10)$, not pigmented. In young balls of basidia, only thick hyphae are present protruding through the stomatal openings, larger (older) balls contain thick hyphae forming basidia and paraphyses that are probably the prolongations of the thin hyphae filling the substomatal chamber.

Basidia holobasidia, cylindrical, delimited at their base by a retraction septum, i.e., the subbasidial cell is empty, without plasm, and collapses, basidia (10-)11-18(-20) $\times 3-4 \mu \mathrm{m}(n=$ 10) when sterigmata are present (not including the sterigmata), sometimes shorter by retraction septa formed during sporulation, each basidium with two apical, straight, or slightly bent sterigmata, (1.5-)2-4 $\mu \mathrm{m}(n=10)$ long, with one basidiospore developing at the tip of each sterigma. After liberation of the basidiospores, basidial cells with scattered tiny remnants of cytoplasm, with scars evident at the tips of the sterigmata.

Basidiospores liberated single or in pairs, two-celled due to a central septum, cylindrical or slightly allantoid and slightly fusoid at the base, with a conspicuous hilum (scar) at the base of each basidiospore, $(11-) 12-16(-18) \times 3-4.5(-5) \mu \mathrm{m}$ $(n=30)$, hyaline, smooth. The two basidiospores of one basidium conjugating by fusing at their bases or individual basidiospores germinating with about $1 \mu \mathrm{m}$ wide hyphae and developing conidia on more or less evident sterigma-like outgrowths or directly developing conidia usually at their tips. Hyphae approx. $1 \mu \mathrm{m}$ wide, septa very difficult to distinguish by light microscopy.

Conidia mostly one-celled, rarely with septum, rod-shaped, sometimes slightly allantoid, or filiform, with more or less evident scar at the point of detachment, $(2-) 3-9(-15) \times$ $(0.5-) 1(-1.5) \mu \mathrm{m}(n=20)$, hyaline, smooth, germinating with thin hyphae or budding forming further conidia (yeast cells).

\section{Discussion}

\section{Morphological structures of species of Brachybasidiaceae}

The presence of balls of basidia formed on the top of stomatal openings by cells originating from fungal stroma in substomatal chambers and protruding through the stomatal openings is a structural feature present in distantly related species of Microstromatales (e.g., Volvocisporium; Begerow et al. 2001; Oberwinkler 2012b; Ritschel et al. 2008), Exobasidiaceae (e.g., Exobasidium oxycocci, illustrated by F. Oberwinkler in Begerow et al. 2001), and Brachybasidiaceae (Brachybasidium, Kordyana, Marantokordyana). Such structures apparently are the result of convergences: If fungal cells are not able to break through the epidermis, they use stomatal openings (Gäumann 1922). Similar strategies for the liberation of spores (not basidiospores) exposed by hyphae protruding through stomatal openings can also be observed for cercosporoid fungi (Mycosphaerellales, Ascomycota), Entylomella spp. (Entylomatales), and Peronosporales (Oomycota) (Piepenbring 2015).

Repeatedly, swellings were documented for thick hyphae in the stroma filling substomatal chambers. They were observed in very thin sections but even in very thin sections, they could not always be distinguished because cells are densely packed and often gelatinized (comp. Gäumann 1922; Berndt and Sharma 1998). In addition, they might be ephemeral because their function may be related to the fact that the fungus needs to force its cells through the stomatal opening or to the development of basidia that need high inner pressure (turgor) for their development. High inner pressure in the substomatal chambers is evident by the fact that the substomatal chambers filled with stroma are swollen (Fig. 4). The swellings may be the place of karyogamy of dikarya and therefore interpreted as probasidia. Gäumann (1922) observed karyogamy and following meiosis in probasidial cells of Brachybasidium pinangae. More or less conspicuous probasidial swellings without observations concerning the nuclei were illustrated repeatedly by F. Oberwinkler (Fig. 1d) and some further authors for Kordyana tradescantiae, Microstroma juglandis (Begerow et al. 2001), Muribasidiospora hesperidium (Begerow et al. 2001), Volvocisporium grewiae (Ritschel et al. 2008), and Volvocisporium triumfetticola (Begerow et al. 2001). Apparently, it is a widely spread structure that is easily overlooked and therefore not useful to distinguish taxa within Brachybasidiaceae. While thick hyphae forming part of the 
stroma filling substomatal chambers are considered basal parts of basidia, thin hyphae of the stroma are supposed to protrude through the stomatal opening and to form paraphyses.

The question whether basidiospores are actively discharged, e.g., ballistosporic, or blastosporic was not addressed by the first authors like Gäumann (1922). Maybe since Cunningham et al. (1976) described "discharged" basidiospores, authors described basidia of Brachybasidiaceae as ballistosporic without critical reflection. Based on own observations and critical interpretation of information in literature, however, basidiospores of Brachybasidiaceae cannot be ballistosporic: (1) The sterigmata of the basidia are straight or stout (e.g., Reid 1976) and not curved as in the case of ballistosporic basidia. (2) According to drawings available in literature and own observations, basidiospores of species of Brachybasidiaceae have broad hila at their basis but no apiculi. There is confusion in the application of the terms "apiculus" and "hilum" (e.g., Reid 1976). The hilum is the area of the attachment of the basidiospore to the basidium, evident as a scar at the basis of the detached basidiospore, while the apiculus is a projection close to the hilum where the Buller's drop develops and causes active liberation of the basidiospore (Piepenbring 2015). (3) Basidiospores of species of Kordyana and Marantokordyana are often found attached to balls of basidia and in pairs. The diaspores responsible for dispersal of these species are the balls of basidia, basidiospores, and conidia.

As typical for species of Basidiomycota classified in heterobasidiomycetes (comp. Piepenbring 2015), the result of the germination of basidiospores is variable. In the case of species of Brachybasidiaceae, basidiospores can fuse by a conjugation bridge, directly form conidia, or germinate forming thin hyphae that produce conidia. Conidia can be cylindrical, rod-shaped, allantoid, fusiform, or globose. The conidia germinate forming hyphae or they produce further spores, often on short outgrowths. Budding conidia can be considered yeast cells. The shape of conidia may be an important characteristic to distinguish systematic groups and species of Exobasidiales (comp. "Dicellomyces" scirpi).

\section{New genus and species of Marantokordyana}

The specimens of Brachybasidiaceae recently collected in Bolivia and Panama are morphologically close to Kordyana spp. by basidia in suprastomatal balls, basidia forming two basidiospores each, and basidiospores germinating after septation with hyphae forming elongate conidia (yeast cells). We classify them in a separate genus new to science because in contrast to species of Kordyana that mostly infect species of Commelinaceae (Commelinales, Commelinidae), the two new species infect species of Marantaceae (Zingiberales,
Commelinidae) and because the two new species form a well-supported monophylum in the molecular phylogenetic analyses. Within Brachybasidiaceae, no species infecting Marantaceae are known up to now. In the phylogenetic tree, the monophylum of the new genus forms part of a polytomy including all the species of Brachybasidiaceae represented by molecular sequence data. Within the family, no specific sister relationship can be distinguished for the members of the new genus. Further described genera differ morphologically by fungal stromata breaking through host tissue, absence of paraphyses, proliferating basidia, and/or different shapes of conidia (comp. Table 1). We consider host specificity on family level as an important argument for the definition of systematic groups, because host specificity has been shown to be indicative of systematic relationships for several systematic groups of Exobasidiales, e.g., Graphiola spp. exclusively on Arecaceae and Exobasidium spp. on Ericaceae and closely related families.

Both species proposed as new species in Marantokordyana infect species of the same genus (Goeppertia, syn. Calathea) and are morphologically very close to each other. The only evident morphological differences are the shorter size of basidia and straighter and shorter sterigmata in M. boliviana with a length of $2-4 \mu \mathrm{m}$ versus $3.5-6.5 \mu \mathrm{m}$ in M. oberwinkleriana. Further, but probably less reliable differences are the yellowish to orange color of the lower side of the leaf spots in $M$. boliviana versus white color in M. oberwinkleriana, and slightly larger balls of basidia in $M$. boliviana. The distinction of the two species is confirmed by differences in sequence data of the ITS and LSU regions of rDNA.

\section{Taxonomy of Kordyana spp.}

During the compilation of species known for Brachybasidiaceae (Online Resource 1), several taxonomic problems were noticed for species of Kordyana: Kordyana indica lacks a diagnosis. Kordyana polliae var. microspora lacks a diagnosis and is considered a synonym of Kordyana polliae by Index Fungorum, but according to the description it may be a species distinct from $K$. polliae. The type species of Kordyana (K. tradescantiae) and most other species described in Kordyana infect species of Commelinaceae, so Kordyana boswelliae on Burseraceae, Kordyana cyphelloidis described from Bignoniaceae, and Kordyana polliniae on Poaceae are doubtful. In addition to the different host family, K. cyphelloidis differs from typical Kordyana spp. by basidiocarps on cancers on leaf blades, leaf petioles, or branches, and by basidia developing from regularly septate hyphae in a hymenium surrounded by a peridium formed by setae with ornamented surface (Viégas 1945). As for many species of Kordyana, morphological characterizations are incomplete and because most of the species of Kordyana lack 
DNA sequence data, it is not possible to clarify these taxonomical problems without new specimens and DNA sequence data.

\section{"Dicellomyces" scirpi}

The species Dicellomyces scirpi is presently classified in the genus Dicellomyces because of morphological similarities with D. gloeosporus, the type species of Dicellomyces, namely by being a plant-parasitic fungus on a grass developing gelatinous stromata breaking through host tissue and by developing bisterigmate basidia with probasidial swellings in a hymenium. The two species differ by their host family (Dicellomyces gloeosporus: Poaceae, D. scirpi: Cyperaceae), the shape of the sori (discoid versus elongated), the presence of paraphyses (absent versus present, described as "hyphidia" by Parmasto 1968), more persistent and evident probasidial swellings in D. gloeosporus, and the shape of conidia formed by germinating basidiospores (globose versus allantoid, also described as "crescentiform") (Ingold 1985; Olive 1945; Parmasto 1968; Reid 1976).

Analyses of LSU sequence data including $D$. gloeosporus and $D$. scirpi resulted in conflicting hypotheses considering the congeneric classification. While Tanaka et al. (2008) revealed monophyly of both Dicellomyces species (support: 72/ 90) being sister taxon of Meira spp. (support: 73/53), Nasr et al. (2019) placed the two Dicellomyces species in different clades with Kordyana spp. as closest relatives of D. gloeosporus (support: 100/99) and Meira spp. as closest relative of D. scirpi (support: 92/62). The results of Nasr et al. (2019) are confirmed by the analyses presented here based on extended data (ITS + LSU) and additional species included (Kordyana brasiliensis, Meira miltonrushii, M. nicotianae). Meira is revealed polyphyletic with Dicellomyces scirpi as closest relative of $M$. nicotianae.

Dicellomyces scirpi most probably does not belong to the genus Dicellomyces, however, we refrain from establishing a new genus for $D$. scirpi, because several other generic concepts are available that are not represented by molecular sequences and therefore not included in the molecular analyses. In order to demonstrate this conclusion, we write the genus name of " $D$." scirpi between quotation marks.

\section{Conclusion}

In the present publication, we draw some taxonomic conclusions for species of Brachybasidiaceae. Many species concepts in this relationship, however, are still incompletely known, because they were only presented by short, incomplete species descriptions in literature. For 12 of now 24 known species of Brachybasidiaceae (Online Resource 1), LSU and for some of them also ITS sequence data are available, only four of seven described genera are included in the phylogenetic analyses. Although species in this group are inconspicuous, without economic importance, and rare, they should be collected, well preserved, and analyzed in order to improve our understanding of this interesting group of fungal plant parasites.

Acknowledgments The specimens of Brachybasidiaceae in Panama were collected with friendly support by Nivardo Avila, Orlando Cáceres, Raiza Duarte, Anika Krohn, Ralph Mangelsdorff, and Martin U. Schmidt. We are grateful to MiAmbiente (formerly ANAM) for collecting and export permits (SE/P-52-07, SE/H-1-09, SE/AH-1-12) to the Universidad Autónoma de Chiriquí (UNACHI) for institutional support. We acknowledge collaboration for fieldwork in Bolivia by participants of the "Curso de Hongos", especially by Noël Murillo. Javier Coimbra is thanked for giving us a cordial welcome in his Finca Arubai and for sharing his fascination with biodiversity in this area. Daniela Camacho, Telma Padilla, and Marisol Toledo made this "Curso de Hongos" possible at the Museo de Historia Natural Noël Kempff Mercado, Universidad Autónoma Gabriel René Moreno, with support by the German Academic Exchange Service. Stephan Beck (Herbario Nacional de Bolivia, La Paz) is thanked for collaboration for the identification of the host plant.

Yalem Meswaet and Kai Reschke contributed to this study by collaborating for sequencing. Carola Glatthorn is thanked for helping to procure publications and to prepare the references to literature.

Barbara Oberwinkler is thanked for diligently taking care of the legacy of Franz Oberwinkler and for her consent to drawings prepared by her deceased husband being included in the present publication.

Funding information Open Access funding provided by Projekt DEAL. This study received financial support from the German Research Foundation (DFG) and from the German Academic Exchange Service (DAAD) for many years.

Open Access This article is licensed under a Creative Commons Attribution 4.0 International License, which permits use, sharing, adaptation, distribution and reproduction in any medium or format, as long as you give appropriate credit to the original author(s) and the source, provide a link to the Creative Commons licence, and indicate if changes were made. The images or other third party material in this article are included in the article's Creative Commons licence, unless indicated otherwise in a credit line to the material. If material is not included in the article's Creative Commons licence and your intended use is not permitted by statutory regulation or exceeds the permitted use, you will need to obtain permission directly from the copyright holder. To view a copy of this licence, visit http://creativecommons.org/licenses/by/4.0/.

\section{References}

Altschul SF, Madden TL, Schäffer AA, Zhang J, Zhang Z, Miller W, Lipman DJ (1997) Gapped BLAST and PSI BLAST: a new generation of protein database search programs. Nucleic Acids Res 25: 3389-3402. https://doi.org/10.1093/nar/25.17.3389

Bauer R, Begerow D, Oberwinkler F (1998) Fortschritte in der Systematik der Brandpilze. Progress in the systematics of smut fungi. Z Pflanzenk Pflanzen 105:224-238

Bauer R, Begerow D, Oberwinkler F, Piepenbring M, Berbee ML (2001) Ustilaginomycetes. In: MacLaughlin DJ, Esser K (eds) The mycota. 
A comprehensive treatise on fungi as experimental systems for basic and applied research. Springer, Berlin, pp 57-80

Begerow D, Bauer R, Oberwinkler F (2001) Muribasidiospora: Microstromatales or Exobasidiales? Mycol Res 105:798-810. https://doi.org/10.1017/S0953756201004208

Begerow D, Bauer R, Oberwinkler F (2002) The Exobasidiales: an evolutionary hypothesis. Mycol Prog 1:187-199

Begerow D, Stoll M, Bauer R (2006) A phylogenetic hypothesis of Ustilaginomycotina based on multiple gene analyses and morphological data. Mycologia 98:906-916. https://doi.org/10.1080/ 15572536.2006.11832620

Begerow D, Schäfer AM, Kellner R, Yurkov A, Kemler M, Oberwinkler F, Bauer R (2014) Ustilaginomycotina. In: McLaughlin DJ, Spatafora JW (eds) The mycota. A comprehensive treatise on fungi as experimental systems for basic and applied research, 2nd edn. Springer, Berlin, pp 299-330

Begerow D, McTaggart A, Agerer R, Frey W (2018) Basidiomycota and Entorrhizomycota, 13. ed. Syllabus of plant families, Adolf Engeler's Syllabus der Pflanzenfamilien ; Part 1/3. Borntraeger, Stuttgart

Berndt R, Sharma ND (1998) Dicellomyces calami sp. nov., from India. Mycol Res 102:1484-1486. https://doi.org/10.1017/ S0953756298006686

Boekhout T, Theelen B, Houbraken J, Robert V, Scorzetti G, Gafni A, Gerson U, Sztejnberg A (2003) Novel anamorphic mite-associated fungi belonging to the Ustilaginomycetes: Meira geulakonigii gen. nov., sp. nov., Meira argovae sp. nov. and Acaromyces ingoldii gen. nov., sp. nov. Int J Syst Evol Microbiol 53:1655-1664. https://doi. org/10.1099/ijs.0.02434-0

Borchsenius F, Suárez LSS, Prince LM (2012) Molecular phylogeny and redefined generic limits of Calathea (Marantaceae). Syst Bot 37: 620-635. https://doi.org/10.1600/036364412X648571

Cao Y, Li P-D, Zhao J, Wang H-K, Jeewon R, Bhoyroo V, Aruna B, Lin F-C, Wang Q (2018) Morph-molecular characterization of Meira nicotianae sp. nov., a novel basidiomycetous, anamorphic yeastlike fungus associated with growth improvement in tobacco plant. Phytotaxa 365:169-181. https://doi.org/10.11646/phytotaxa.365.2. 4

Castresana J (2000) Selection of conserved blocks from multiple alignments for their use in phylogenetic analysis. Mol Biol Evol 17:540 552. https://doi.org/10.1093/oxfordjournals.molbev.a026334

Crous PW, Groenewald JZ, Carroll G (2003) Muribasidiospora indica causing a prominent leaf spot disease on Rhus lancea in South Africa. Aust Plant Pathol 32:313-316

Cunningham JL, Bakshi BK, Lentz PL, Gilliam MS (1976) Two new genera of leaf-parasitic fungi (Basidiomycetidae: Brachybasidiaceae). Mycologia 68:640-654. https://doi.org/10. 1080/00275514.1976.12019948

de Beer ZW, Begerow D, Bauer R, Pegg GS, Crous PW, Wingfield MJ (2006) Phylogeny of the Quambalariaceae fam. nov., including important Eucalyptus pathogens in South Africa and Australia. Stud Mycol 55:289-298. https://doi.org/10.3114/sim.55.1.289

Donk MA (1931) Revisie van de Nederlandse Heterobasidiomycetae en Homobasidiomycetae - Aphyllophoraceae I. Medded Nedl Mycol Ver 18-20:67-200

Felsenstein J (1981) Evolutionary trees from DNA sequences: a maximum likelihood approach. J Mol Evol 17:368-376

Gardes M, Bruns TD (1993) ITS primers with enhanced specificity for basidiomycetes-application to the identification of mycorrhizae and rusts. Mol Ecol 2:113-118. https://doi.org/10.1111/j.1365-294X. 1993.tb00005.x

Gatesy J, DeSalle R, Wheeler W (1993) Alignment-ambiguous nucleotide sites and the exclusion of systematic data. Mol Phylogenet Evol 2:152-157. https://doi.org/10.1006/mpev.1993.1015

Gäumann E (1922) Über die Gattung Kordyana Rac. Ann Mycol 20:257_ 271
Gäumann E (1926) Vergleichende Morphologie der Pilze. Gustav Fischer, Jena

Giribet G, Wheeler WC (1999) On gaps. Mol Phylogenet Evol 13:132143. https://doi.org/10.1006/mpev.1999.0643

Hammel BE, Grayum MH, Herrera C, Zamora N (2003) Manual de plantas de Costa Rica. Gimnospermas y Monocotiledóneas (Agavaceae-Musaceae), II. Missouri Botanical Garden, St. Louis

Huelsenbeck JP, Rannala B (2004) Frequentist properties of Bayesian posterior probabilities of phylogenetic trees under simple and complex substitution models. Syst Biol 53:904-913. https://doi.org/10. 1080/10635150490522629

Huelsenbeck JP, Larget B, Miller RE, Ronquist F (2002) Potential applications and pitfalls of Bayesian inference of phylogeny. Syst Biol 51:673-688. https://doi.org/10.1080/10635150290102366

Ingold CT (1985) Dicellomyces scirpi: its conidial stage and taxonomic position. T Brit Mycol Soc 84:542-545. https://doi.org/10.1016/ S0007-1536(85)80021-8

Jørgensen PM, Nee MH, Beck SG (eds) (2014) Catálogo de las plantas vasculares de Bolivia. Monographs in systematic botany, vol. 127. Missouri Botanical Garden Press, St. Louis

Judith C, Rossman AY, Kennedy AH, Cáceres O, Piepenbring M (2015) Microchrysosphaera graminicola, an enigmatic new genus and species in the Hypocreales from Panama. Mycol Prog 14:72. https://doi. org/10.1007/s11557-015-1095-2

Katoh K, Standley DM (2013) MAFFT multiple sequence alignment software version 7. Improvements in performance and usability. Mol Biol Evol 30:772-780. https://doi.org/10.1093/molbev/mst010

Kirk P (2019) Index Fungorum. http://www.indexfungorum.org/. Accessed repeatedly during 2019

Kottke I, Suarez JP, Herrera P, Cruz D, Bauer R, Haug I, Garnica S (2010) Atractiellomycetes belonging to the 'rust' lineage (Pucciniomycotina) from mycorrhizae with terrestrial and epiphytic neotropical orchids. Proc R Soc B Biol Sci 277:1289-1298. https:// doi.org/10.1098/rspb.2009.1884

Kress WJ, Erickson DL, Jones FA, Swenson NG, Perez R, Sanjur O, Bermingham E (2009) Plant DNA barcodes and a community phylogeny of a tropical forest dynamics plot in Panama. Proc Natl Acad Sci U S A 106:18621-18626. https://doi.org/10.1073/pnas. 0909820106

Kruse J, Choi Y-J, Thines M (2017) New smut-specific primers for the ITS barcoding of Ustilaginomycotina. Mycol Prog 16:213-222. https://doi.org/10.1007/s11557-016-1265-x

Macedo DM, Pereira OL, Hora Júnior BT, Weir BS, Barreto RW (2016) Mycobiota of the weed Tradescantia fluminensis in its native range in Brazil with particular reference to classical biological control. Australas Plant Path 45:45-56. https://doi.org/10.1007/s13313015-0388-x

Maier W, Khoza T, Harmse N, Wingfield BD, Wingfield MJ (2006) A disease epidemic on Zizyphus mucronata in the Kruger National Park caused by Coniodictyum chevalieri. Stud Mycol 55:279-288. https://doi.org/10.3114/sim.55.1.279

Matheny PB, Gossmann JA, Zalar P, Kumar TA, Hibbett DS (2006) Resolving the phylogenetic position of the Wallemiomycetes: an enigmatic major lineage of Basidiomycota. Can J Bot 84:1794 1805. https://doi.org/10.1139/b06-128

Michelangeli FA, Penneys DS, Giza J, Soltis D, Hills MH, Skean JD Jr (2004) A preliminary phylogeny of the tribe Miconieae (Melastomataceae) basd on nrITS sequence data and its implications on inflorescence position. Taxon 53:279-290. https://doi.org/10. $2307 / 4135608$

Nasr S, Lutz M, Amoozegar MA, Eparvier V, Stien D, Fazeli SAS, Yurkov A (2019) Graphiola fimbriata: the first species of Graphiolaceae (Exobasidiales, Basidiomycota) described only based on its yeast stage. Mycol Prog 18:359-368. https://doi.org/ 10.1007/s11557-018-1450-1 
Oberwinkler F (1982) The significance of the morphology of the basidium in the phylogeny of Basidiomycetes. In: Starr MP, Wells K, Wells EK, Gruen HE, Lu BC, McLaughlin DJ, Oberwinkler F, Thielke C, Uno F (eds) Basidium and basidiocarp. Evolution, cytology, function, and development. Springer, New York, pp 9-35

Oberwinkler F (2012a) Evolutionary trends in Basidiomycota. Stapfia 96: 45-104

Oberwinkler F (2012b) Mykologie am Lehrstuhl Spezielle Botanik und Mykologie der Universität Tübingen, 1974-2011. Andrias 19:23110

Oberwinkler F, Bandoni RJ, Blanz P, Deml G, Kisimova-Horovitz L (1982) Graphiolales: Basidiomycetes parasitic on palms. Plant Syst Evol 140:251-277

O'Donnel KL (1992) Ribosomal DNA internal transcribed spacers are highly divergent in the phytopathogenic ascomycete Fusarium sambucinum (Gibberella pulicaris). Curr Genet 22:213-220. https://doi.org/10.1007/BF00351728

O'Donnel KL (1993) Fusarium and its near relatives. In: Reynolds DR, Taylor JW (eds) The fungal holomorph. Mitotic, meiotic and pleomorphic speciation in fungal systematics: proceedings of an international symposium, Newport, Oregon, 4-7 august 1992. CAB International, Wallingford, pp 225-233

Olive LS (1945) A new Dacrymyces-like parasite of Arundinaria. Mycologia 37:543-552. https://doi.org/10.2307/3754691

Parmasto E (1968) A new species and a new family of the Aphyllophorales. Eesti NSV Teaduste Akadeemia toimetised / Proc Acad Estonia SSR 17:223-228

Patouillard N, von Lagerheim G (1892) Champignons de l'équateur (Pugillus II.). B Soc Mycol Fr 8:113-140

Piątek M, Riess K, Karasiński D, Yorou NS, Lutz M (2016) Integrative analysis of the West African Ceraceosorus africanus sp. nov. provides insights into the diversity, biogeography, and evolution of the enigmatic Ceraceosorales (Fungi. Ustilaginomycotina). Org Divers Evol 16:743-760. https://doi.org/10.1007/s13127-016-0285-3

Piepenbring M (2015) Introduction to mycology in the tropics. The American Phytopathological Society, St.Paul

Piepenbring M, Espinoza J, Saldana L, Cáceres O (2010) New records, host plants, morphological and molecular data of Exobasidiales (Basidiomycota) from Panama. Nova Hedwigia 91:231-242. https://doi.org/10.1127/0029-5035/2010/0091-0231

Piepenbring M, Nold F, Trampe T, Kirschner R (2012a) Revision of the genus Graphiola (Exobasidiales, Basidiomycota). Nova Hedwigia 94:67-96. https://doi.org/10.1127/0029-5035/2012/0094-0067

Piepenbring M, Hofmann TA, Unterseher M, Kost G (2012b) Species richness of plants and fungi in western Panama: towards a fungal inventory in the tropics. Biodivers Conserv 21:2181-2193. https:// doi.org/10.1007/s10531-011-0213-y

Piepenbring M, Begerow D, Kirschner R, Yang ZL (2019) Editorial to the topical collection dedicated to Prof. Dr. Franz Oberwinkler. Mycol Prog 18:313-319. https://doi.org/10.1007/s11557-018-1454-x

Raciborski M (1900) Parasitische Algen und Pilze Java's. II. Teil. Bibl Mycol 37:1-46

Reid DA (1976) Dicellomyces scirpi (Basidiomycetes) new to Britain. T Brit Mycol Soc 66:536-538. https://doi.org/10.1016/S00071536(76)80232-X

Ritschel A, Begerow D, Oberwinkler F (2008) A new species of Volvocisporium from Namibia, V. grewiae sp. nov. (Microstromatales, Ustilaginomycota). Mycol Prog 7:1-5. https:// doi.org/10.1007/s11557-007-0546-9

Ronquist F, Teslenko M, van der Mark P, Ayres DL, Darling A, Höhna S, Larget B, Liu L, Suchard MA, Huelsenbeck JP (2012) MrBayes 3.2: efficient Bayesian phylogenetic inference and model choice across a large model space. Syst Biol 61:539-542. https://doi.org/10.1093/ sysbio/sys029
Schoch CL, Robbertse B, Robert V, Vu D, Cardinali G, Irinyi L, Meyer W, Nilsson RH, Hughes K, Miller AN, Kirk PM, Abarenkov K, Aime MC, Ariyawansa HA, Bidartondo M, Boekhout T, Buyck B, Cai Q, Chen J, Crespo A, Crous PW, Damm U, de Beer ZW, Dentinger BTM, Divakar PK, Dueñas M, Feau N, Fliegerova K, García MA, Ge Z-W, Griffith GW, Groenewald JZ, Groenewald M, Grube M, Gryzenhout M, Gueidan C, Guo L, Hambleton S, Hamelin R, Hansen K, Hofstetter V, Hong S-B, Houbraken J, Hyde KD, Inderbitzin P, Johnston PR, Karunarathna SC, Kõljalg U, Kovács GM, Kraichak E, Krizsan K, Kurtzman CP, Larsson K$\mathrm{H}$, Leavitt S, Letcher PM, Liimatainen K, Liu J-K, Lodge DJ, Luangsa-ard JJ, Lumbsch HT, Maharachchikumbura SSN, Manamgoda D, Martín MP, Minnis AM, Moncalvo J-M, Mulè G, Nakasone KK, Niskanen T, Olariaga I, Papp T, Petkovits T, PINOBODAS R, Powell MJ, Raja HA, Redecker D, Sarmiento-Ramirez JM, Seifert KA, Shrestha B, Stenroos S, Stielow B, Suh S-O, Tanaka K, Tedersoo L, Telleria MT, Udayanga D, Untereiner WA, Diéguez Uribeondo J, Subbarao KV, Vágvölgyi C, Visagie C, Voigt K, Walker DM, Weir BS, Weiß M, Wijayawardene NN, Wingfield MJ, Xu JP, Yang ZL, Zhang N, Zhuang W-Y, Federhen S (2014) Finding needles in haystacks: linking scientific names, reference specimens and molecular data for fungi. Database: J Biol Databases Curation 2014. https://doi.org/10.1093/database/bau061

Sepúlveda G, Arismendi M, Huanca-Mamani W, Cárdenas-Ninasivincha S, Salvatierra R, Latorre B (2017) The presence of false smut (Graphiola phoenicis) on Canary date palm (Phoenix canariensis) in Easter Island, Chile. Cien Inv Agric 44:307-311. https://doi.org/ 10.7764/rcia.v44i3.1787

Stamatakis A (2014) RAxML version 8: a tool for phylogenetic analysis and post-analysis of large phylogenies. Bioinformatics 30:13121313. https://doi.org/10.1093/bioinformatics/btu033

Stamatakis A (2016) The RAxML v8.2.X manual. Institute for Theoretical Studies, Heidelberg

Stamatakis A, Hoover P, Rougemont J (2008) A rapid bootstrap algorithm for the RAxML web servers. Syst Biol 57:758-771. https:// doi.org/10.1080/10635150802429642

Stanford AM, Harden R, Parks CR (2000) Phylogeny and biogeography of Juglans (Juglandaceae) based on matK and ITS sequence data. Am J Bot 87:872-882. https://doi.org/10.2307/2656895

Tanaka E, Shimizu K, Imanishi Y, Yasuda F, Tanaka C (2008) Isolation of basidiomycetous anamorphic yeast-like fungus Meira argovae found on Japanese bamboo. Mycoscience 49:329-333. https://doi. org/10.1007/s10267-008-0429-1

Viégas AP (1945) Alguns fungos do Brasil VII - VIII. Bragantia 5:25329016 plates

Wang Q-M, Begerow D, Groenewald M, Liu X-Z, Theelen B, Bai F-Y, Boekhout T (2015) Multigene phylogeny and taxonomic revision of yeasts and related fungi in the Ustilaginomycotina. Stud Mycol 81: 55-83. https://doi.org/10.1016/j.simyco.2015.10.004

White TJ, Bruns T, Lee S, Taylor JW (1990) Amplification and direct sequencing of fungal ribosomal RNA genes for phylogenetics. In: Innis MA, White TJ, Sninsky JJ (eds) PCR protocols. A guide to methods and applications, vol 18. Academic Press, San Diego, pp 315-322

Woodson RE Jr, Schery RW (1943) Flora of Panama part II. Fascicle 1. Ann Mo Bot Gard 30:97-403

Yasuda F, Yamagishi D, Akamatsu H, Izawa H, Kodama M, Otani H (2005) Fruit stain of Japanese pear caused by basidiomycetous, yeast-like fungi, Acaromyces ingoldii and Meira sp. Jpn J Phytopathol 71:156-165. https://doi.org/10.3186/jjphytopath.71. 156

Publisher's note Springer Nature remains neutral with regard to jurisdictional claims in published maps and institutional affiliations. 